\title{
Indonesian Islam in Interwar Europe: Muslim Organizations in the Netherlands and Beyond
}

\author{
Klaas Stutje \\ Introduction
}

Depending on the one's interpretation, Muslim life during the interwar period in the Netherlands can either be characterized as "Indonesian," "Dutch" or "European." Although Muslims in the Netherlands looked to the heartland of Islam for religious guidance, it was primarily their immigrant Indonesian status and their socioeconomic position in the Netherlands that determined the character of Muslim life there. The number of Muslim residents in the Netherlands before World War II was relatively low compared to the large Muslim populations in other western European colonial centers. And although they succeeded in building organizations and infrastructures of their own, the absence of large-scale postcolonial Muslim migration to the Dutch metropole, and the fact that the first official mosque was only established in 1955, has meant that research on Muslim life in the Netherlands has predominantly focused on postwar migrant workers from Morocco and Turkey who arrived during the 1960s and after. Indonesians in the Netherlands in the pre World War II period have rarely been taken into account. ${ }^{1}$

In the coming pages, I aim to write the Dutch chapter of the history of Islam in interwar Europe by focusing on Indonesian Muslim groups in the Netherlands before World War II. This field of research has remained understudied in two ways. First, the Netherlands has remained largely beyond the scope of recent publications on the presence of Islam in interwar Europe, despite the fact that

1 Harry A. Poeze, In het Land van de Overheerser, I: Indonesiërs in Nederland 1600-1950 (Dordrecht: Foris Publications Holland, 1986). Cf. Nico Landman, Van Mat tot Minaret: de Institutionalisering van de Islam in Nederland (Amsterdam: vu Uitgeverij, 1992): 20-21; W.A.R. Shadid and P.S. van Koningsveld, Islam in Nederland en België: Religieuze Institutionalisering in Twee Landen met een Gemeenschappelijke Voorgeschiedenis (Leuven/ Paris/Dudley, MA: Peeters, 2008), 22. 
it had a considerable Muslim population under its imperial rule. ${ }^{2}$ Second, in the context of studies on the Dutch colonial past, research on Indonesian migration to the Netherlands has remained limited to political activities, for example, of the well-known Indonesian students association Perhimpoenan Indonesia. ${ }^{3}$ The Muslim identity of most of the Indonesian students, and of the Indonesian migrant community as a whole was not addressed. In 1967, the American anthropologist Joan Schutzman Wider was the first to devote a few pages on Perkoempoelan Islam - the only Islamic organization in the Netherlands before World War II - in an unpublished dissertation on postwar Indonesian domestic workers in the Netherlands; this work was followed in 1986 by a brief account by the Dutch historian Harry Poeze. ${ }^{4}$ It was only in 2012 that the Leiden historian Umar Ryad published a comprehensive article on Muslim life in the Netherlands; in it he focuses on the chief Muslim organizer and convert Mohammad Ali van Beetem and his role in the Indonesian community in the Netherlands. ${ }^{5}$ Ryad's article touches upon most of the organizational aspects of Muslim life in the decades before the war, but usually from the perspective of its central figure Van Beetem.

This chapter seeks to position Perkoempoelan Islam and its members more clearly within the landscape of the various Indonesian and other migrant communities in the Netherlands, and subsequently among the 'colonial' Muslim communities of Europe as well. This leads to a better understanding of the functions of Perkoempoelan Islam, and of its loyalist stance vis-à-vis the Dutch

2 Cf. Nathalie Clayer and Eric Germain, eds. Islam in Inter-War Europe (London: Hurst \& Company, 2008).

3 John Ingleson, Perhimpunan Indonesia and the Indonesian Nationalist Movement, 1923-1928 (Melbourne: Monash University, 1975); Harsja W. Bachtiar, "The Development of a Common National Consciousness among Students from the Indonesian Archipelago in the Netherlands," Majalah Ilmu-Ilmu Sastra Indonesia 6 (1976): 31-44; Poeze, In het Land van de Overheerser.

4 Joan Schutzman Wider, "Indonesian Women in The Hague: Colonial Immigrants in the Metropolis" (PhD diss., New York University, 1967), 82-86; Poeze, In het Land van de Overheerser, 288-290, 316-318. Cf. Annemarie Cottaar, Ik had een Neef in Den Haag: Nieuwkomers in de Twintigste Eeuw (Zwolle: Waanders, 1998), 81-82; René Karels, Mijn Aardse Leven Vol Moeite en Strijd:Raden Mas Noto Soeroto, Javaan, Dichter, Politicus 1888-1951 (Leiden: KITLV Uitgeverij, 2010), 93, 96-97, 174-175.

5 Umar Ryad, "Among the Believers in the Land of the Colonizer: Mohammed Ali van Beetem's Role Among the Indonesian Community in the Netherlands in the Interwar Period," Journal of Religion in Europe 5 (2012): 273-310; Umar Ryad, "Te Gast in Den Haag: Discussies Moskeebouw in Nederland vóór de Tweede Wereldoorlog," Tijdschrift voor Religie, Recht en Beleid 4 (2013): 59-78. 
government. It also helps to accurately assess its religious engagements with Muslim organizers abroad.

Three issues in particular are addressed in this chapter. First, I describe the various Indonesian communities in the Netherlands and their infrastructures, with special attention to the workers in Perkoempoelan Islam. Second, I examine the attitude of Dutch authorities towards Muslim organizations. This also determined the ability of an organization such as Perkoempoelan Islam to negotiate on behalf of Indonesian Muslims. In a third section, I evaluate the various international contacts of Indonesian Muslims with networks in Europe. Here, I not only assess primarily Islamic engagements, but also include contacts with anticolonial networks and with Cairo. These events were part of the Islamic landscape of Dutch Indonesian Muslims as well.

In writing the history of Islam in the Netherlands it is useful to distinguish between the practicing of faith by individuals, and the organization of Muslims as a group. With regards to the former, it is remarkable that the various autobiographies and personal accounts by Indonesians in the Netherlands, who often became dignitaries in the period of independence, are strictly confined to the political sphere and offer scant information on their practices and beliefs during their Dutch years. Nevertheless, I assume that throughout the period of Indonesian migration to Europe, Muslims to some extent continued to observe the religious duties of Islam on their own initiative and in the private sphere. ${ }^{6}$ It is implausible to suggest that the Indonesians only became more 'religious' or devout once Perkoempoelan Islam was established in May 1932. At the organizational level, however, Muslim life did find its first embodiment with the establishment of Perkoempoelan Islam. ${ }^{7}$

\section{Indonesian Communities in the Netherlands}

The Dutch Indonesian community can be subdivided into three groups. The first group consisted of Indonesian students who arrived from the last decades of the nineteenth century onwards, and with greater numbers after World War I. The cohorts of students before the war were predominantly of Javanese aristocratic descent; this was a class that was dependent on the Dutch colonial administration for its wealth and social position. Unable to maintain

6 Cf. Schutzman Wider, "Indonesian Women in The Hague," 80-86.

7 Harry A. Poeze, Politiek-Politioneele Overzichten van Nederlandsch-Indië: Deel IV (Dordrecht: Foris Publications Holland, 1994), lxxviii. 
the traditional way of life, many lower aristocratic families chose to adapt to the new power system and sent their sons to Europe for some years of higher education. ${ }^{8}$ After World War I, with the native rubber industry booming, the social make-up of the student community in the Netherlands changed somewhat and wealthy merchant families started to send their children overseas as well. These Indonesian students lived predominantly in the university cities of Leiden and Delft, although all university towns in the Netherlands attracted students from the Dutch East Indies. Their number can be estimated from a few dozen in the first two decades, to up to two hundred people in the peak years before the Great Depression. ${ }^{9}$

A much larger group of Indonesian shopkeepers, restaurant-owners, and their personnel began to arrive in Dutch urban centers from 1900 onwards. Together with Indonesian domestic workers (baboes or iboes) that traveled along with their Dutch employers on leave, they formed the largest group of Indonesians in the Netherlands. A considerable Indonesian community emerged in The Hague, alongside Dutch families with a colonial background (verlofgangers) temporarily residing in the Dutch metropole. ${ }^{10}$ In general, the Indonesian workers and retailers in The Hague were from a less wealthy background than the students residing in Leiden and Delft. This class of people has received less attention from scholars, probably because they left fewer written sources than their student compatriots, and also because their political behavior was less outspoken. Nonetheless, their shops and restaurants today are the most visible reminders of the Dutch-Indonesian communities from before the war.

A third considerable group of Indonesians in the Netherlands consisted of dockers, sailors, and stewards on cargo and passenger ships that commuted to and from the colony. Of this last group little is known. Most of them were in the Netherlands only temporarily, and while on leave they usually stayed on their ships or in boarding houses in the harbor districts of Rotterdam and Amsterdam. There was a lively black market of colonial and European wares and clandestine literature, but despite the targeted attempts of communists to bring the transient sailors into contact with Dutch and Indonesian-Dutch political

8 H.A. Sutherland, The Making of a Bureaucratic Elite: the Colonial Transformation of the Javanese Priyayi (Singapore: Heinemann Educational Books, 1979), 144.

$9 \quad$ Poeze, In het Land van de Overheerser.

10 Cottaar, Ik had een Neef in Den Haag, 72-75; Karels, Mijn Aardse Leven Vol Moeite en Strijd, 170 . 
organizations, there was only incidental political or organizational cooperation with other Indonesian communities. ${ }^{11}$

\section{Indonesian Organizations in the Netherlands}

As stated above, most studies on Dutch Indonesian organizational infrastructure have focused on the organizational history of the first group. They describe how, in 1908, students established an 'Indies' association (the Indische Vereeniging) to provide an environment where they could socialize, where newcomers could find welcoming support, and where contact with the motherland could be maintained. This organization was closely connected to the general academic life in Leiden and other university towns. Many of the members of the Indische Vereeniging were also members of elite Dutch student societies; the so-called corpora or fraternities. With regard to colonial policy, most students initially adhered to the associationist liberal school of the 'ethici,' which also found strong support among prominent Leiden professors. ${ }^{12}$ These students advocated moderate political reforms in the colony, with an emphasis on modernization and development. Nonetheless, they believed these reforms should take place under Dutch guidance, and hence the 'ethici' remained loyal to Dutch rule over the colony.

In 1923, a nationalistic student organization broke away from the loyalist majority and started to agitate against the Dutch colonial administration. This organization, Perhimpoenan Indonesia ('Indonesian Association'), caused much upheaval in the Dutch media and governmental circles. Its leaders, such as Hatta, Sjahrir, and Sastroamidjojo, who later became prominent political figures in Indonesia, were constantly in the spotlights of security forces and the media, and consequently of scholars as well. ${ }^{13}$

11 Schutzman Wider, "Indonesian Women in The Hague," 191-197; Cottaar, Ik had een Neef in Den Haag, 79 .

12 Among Dutch imperial historians the 'ethical' tradition refers to a set of reformist social liberal ideas on colonial development that was current in the first decades of the twentieth century among colonial ideologues and politicians. As such, it does not bear a normative connotation. For a study on the manifold character of the ethical political tradition, see Elsbeth Locher-Scholten, Ethiek in fragmenten. Vijf studies over koloniaal denken en doen van Nederlanders in de Indonesische Archipel 1877-1942 (Utrecht: Hes Publishers, 1981), 176-208.

Ingleson, Perhimpunan Indonesia and the Indonesian Nationalist Movement, 34. 
Social formations among the other permanent Indonesian community in the Netherlands - the retailers, the cooks, and the domestic workers in the urban centers of Holland-attracted much less attention. They were less inclined to pursue radical political aims, they were oriented on self-help and mutual aid, and were not integrated into the higher social, political or academic strata of Dutch society. As such they had a truly subaltern character, both with regard to their highly vulnerable and somewhat invisible social position, and in terms of their subsequently poor historiographical representation by historians and social scientists. It is precisely among these classes that Perkoempoelan Islam found its origins. The organization was mainly active in The Hague; it began in 1932 with sixty members but gradually grew to roughly 300 members around 1940 . According to the articles of the association, Perkoempoelan aimed to facilitate the observance of the commandments of Islam, to promote a feeling of mutual brotherhood among its members, and to maintain relations with members of other religions in the Netherlands. Its most immediate ambition was to establish a Muslim cemetery and a community building annex mosque in The Hague, where most Muslims lived. ${ }^{14}$

\section{Characterizing the Perkoempoelan Islam in the Netherlands}

In characterizing Perkoempoelan Islam and its role in the Indonesian community three aspects should be mentioned: the socio-political views of its most prominent members, the crucial role of ordinary members in organizing The Hague's Muslims, and the social and representative functions of this religious association.

With regard to the first issue, one of the initiators of Perkoempoelan Islam and its most conspicuous member, Mohammed Ali van Beetem, is rather atypical. Umar Ryad has already devoted considerable attention to this Dutch convert, born Jean Louis Charles van Beetem, he converted to Islam in a public ceremony in $1931 .{ }^{15}$ His political character was much more pronounced than the views of ordinary Indonesian workers. Before this retired marine officer began to lobby for the establishment of a mosque and a Muslim organization

14 "Indië in Nederland," De Indische courant (29 February 1932); Ryad, "Among the Believers," 290-291.

15 Ryad, "Among the Believers"; Poeze, In het Land van de Overheerser, 196, 288-290. On Van Beetem, Oedaya, and Noto Soeroto: Karels, Mijn Aardse Leven Vol Moeite en Strijd, 93, 96-97. 
in the Netherlands at the end of the 1920s, he engaged in various national relief campaigns for the Dutch East Indies, and contributed to the conservative colonial journal Oedaya.

In 1929 he stood in the Dutch parliamentary elections for a short-lived ultranationalist party, the Bond van Nationalisten. In public meetings Van Beetem advocated a tough Dutch nationalist policy, fulminating against socialism and social-democracy, and loudly opposing the often heard Indonesian secessionist slogan "Indië los van Holland, nu!" ("The Indies apart from Holland, now!"). ${ }^{16}$ This brought Van Beetem into conflict with the nationalistic students in Perhimpoenan Indonesia, who called him a fascist and refused further cooperation. Concurrently, however, Van Beetem started to campaign for the establishment of a mosque in The Hague. ${ }^{17}$

For Van Beetem, this combination of ideas was less contradictory than it might seem. The promotion of Muslim interests by Van Beetem was not part of an anticolonial agenda, as was the case with Permi (Persatoean Muslimin Indonesia) and other contemporary Islamist organizations in the Dutch East Indies. Rather, the idea that the Dutch Muslim community was in need of its own societal institutions must be interpreted as part of a conservative agenda of 'sphere sovereignty.' In the Dutch context, this concept found strong support among Reformed Christian and Catholic leaders from the end of the nineteenth century onwards; they were defending their socio-religious sphere of influence against other denominations and against the state. This belief in political and socio-religious sovereignty, often referred to as 'pillarization,' was dominant throughout the first half of the twentieth century, and was also applied to the accommodation of foreign refugees and migrants, such as Catholic miners from Slovenia and Poland. Non-Christian migrant groups, such as Jewish refugees from Eastern Europe and Russia, Chinese workers in the Dutch harbors, and Indonesian workers in The Hague, had to build their own supportive social structures, and it was to this end that Mohammed Ali van Beetem worked. ${ }^{18}$

16 "Verbond van Nationalisten," Nieuwsblad van het Noorden (10 March 1928); "Verbond van Nationalisten," Het Vaderland (26 March 1929); "Verkiezingen Tweede Kamer, de candidaatstelling," Het Vaderland (21 May 1929); Mohammad Hatta, "De lezing van Stokvis voor de 'Perhimpoenan Indonesia," De Socialist (8 June 1929); "Perhimpoenan Indonesia; de ervaringen van Stokvis," De Sumatra Post (8 July 1929).

17 J.L.Ch. van Beetem, "Een Moskee in Den Haag," Het Vaderland (15 June 1929).

18 Jan Lucassen and Leo Lucassen, Winnaars en Verliezers: Een Nuchtere Balans van Vijfhonderd Jaar Immigratie (Amsterdam: Uitgeverij Bert Bakker, 2012), 174-185. 


\section{Rank and File}

Less politically outspoken than Mohammed Ali van Beetem, but more representative of the rank and file of Perkoempoelan Islam, were the other founding members 'Baas' N. Oesim and Saiman (alias Pak Bouman). The former, who was secretary for Perkoempoelan Islam, and its driving force after the death of Van Beetem in 1938, worked as a cook in a restaurant, the Soekoe Manah on Groot Hertoginnelaan in The Hague. The latter, Saiman, opened an Indonesian restaurant in 1922 together with his wife. More than once, Saiman proved central to the Indonesian workers community. His restaurant, Senang Atie, was located just across from Van Beetem's house, at Balistraat 70, and with traditional food at low prices it was a popular meeting place for Indonesian workers. The preparatory meetings for the establishment of Perkoempoelan Islam were held in Saiman's restaurant; ceremonial slametan-dinners and lebaranfestivities, to celebrate the end of Ramadan, were organized in his house at Obrechtstraat 117 (see Figure 6.1). ${ }^{19}$

Although Saiman and Oesim were very active in organizing the Muslim community in The Hague, they did not engage in overt politics. Whereas Van Beetem was active in various conservative organizations and campaigns, the names of Oesim and Saiman were nowhere to be found in other Indonesian political organizations or official festivities. In this respect, it is important to remember that most of the Indonesian workers were illiterate and did not speak Dutch very well. ${ }^{20}$

At least until the establishment of a community building, the religious and social life of Perkoempoelan Islam was centered around individuals and their respective homes. Van Beetem, Saiman, and Oesim were very energetic in attracting new members and in realizing a basic Islamic infrastructure. In $193^{2}$ they negotiated with the local government to designate an Islamic section in the public cemetery of The Hague, and in 1935 they established a langgar at Hugo de Grootstraat 31 in that same city. ${ }^{21}$ Van Beetem's house was open to all

19 "Islamieten Vereeniging," Algemeen Handelsblad (9 October 1932); "Brieven uit het Moederland," Het Nieuws van den Dag voor Nederlandsch-Indië (28 October 1932); Poeze, In het Land van de Overheerser, 238.

20 Schutzman Wider, "Indonesian Women in The Hague," 170, 217, 222.

21 "Islamietische Begraafplaats," Het Vaderland (24 December 1932); "Perkoempoelan Islam," Het Vaderland (4 March 1935); Schutzman Wider, "Indonesian Women in The Hague," 84. In the southeast Asian context a langgar is a mosque, but smaller, privately owned and usually attached to or part of a house, see Clifford Geertz, The Religion of Java (Chicago: University of Chicago Press, 1976), 181. 
Indonesian Muslims as a taman persaudaraan, 'house of brothers,' and meetings often took place in Saiman's restaurant.

Other members supported the association as well. The apartments of Kassanna and Mar Kasim at Obrechtsstraat 431 in The Hague, the boarding house Persinggahan at Van Boetzelaerlaan 2, and café De Groothertogin at Groot Hertoginnelaan in the same city were also prominent locations. ${ }^{22} \mathrm{~A}$ special communal function was performed by Indonesian iboes-the female domestic workers and nannies that worked with Dutch colonial families on leave. Though they remained completely absent from official accounts, they played an important role in preparing the ceremonial and religious slametanmeals. On special occasions, such as funerals, weddings or with the lebaran feast that marks the end of Ramadan, they came together to prepare meals, thereby facilitating the religious ceremonies and enhancing social cohesion among the Indonesian workers community as a whole. ${ }^{23}$

Socially, Perkoempoelan Islam, the only Muslim association in the Netherlands, functioned primarily as a communal organization in which workers found a welcoming environment. Politically, its character was mainly determined by Van Beetem's conservative views, but these were perhaps more visible from the outside than within the workers community itself. It may have prevented, however, cooperation between the organization and the politically outspoken anticolonial students in Perhimpoenan Indonesia. Although the latter organization was in favor of inter-communal, inter-religious, and interregional unity and solidarity, they also required, as a fundamental precondition for cooperation, an anticolonial and non-cooperative stance towards the Dutch state.

Conversely, Perhimpoenan Indonesia was not a serious partner for the Indonesian workers in Perkoempoelan Islam. Not only was the student association inter-religious, and therefore non-Islamic because of its multi-religious membership, but more importantly, Perhimpoenan Indonesia was deemed too elitist, and insensitive to the immediate problems of their poorer compatriots. As Schutzman Wider indicates in her examination of Dutch Indonesian workers after World War II, differences in social background often prevented structural cooperation between the two groups. ${ }^{24}$

\footnotetext{
22 "Viering van het Indisch Nieuwjaar," Het Vaderland (28 January 1933); Landman, Van Mat tot Minaret, 21.

23 Schutzman Wider, "Indonesian Women in The Hague," 86-91, 199-200.

24 Ibid., 214.
} 


\section{Social and Representative Functions and the Negotiation of Space}

In fact, in the Indonesian organizational landscape, Perkoempoelan Islam was the only body that could represent Indonesian workers in socio-economic matters vis-à-vis the local or national government. Other organizations in the Netherlands, such as Perhimpoenan Indonesia and Roekoen Peladjar Indonesia (established in 1936) were predominantly focused on students. Moreover, other organizations either explicitly refrained from political action and narrowed their activities to the cultural sphere, as was the case with Roekoen Peladjar Indonesia and the Indo-Chinese association Chung Hwa Hui, or they consciously exercised 'big-politics' with regard to the situation in the Dutch East Indies, as was the case with Perhimpoenan Indonesia. Mutual aid or practical representation were not among the latter's fields of interests.

This aid was, however, urgently required as the Great Depression devastated the world in the 1930s. The Indonesian workers were particularly vulnerable in the disastrous economic situation. The Dutch East Indies were hard hit by the depression, and one-sixth of the large European and Eurasian population were unemployed during this period. ${ }^{25} \mathrm{~A}$ considerable number chose to migrate to the motherland, but were unable to find employment there either. ${ }^{26}$ Indonesian domestic workers and cooks that had followed their employers, the Indies families, to The Hague were dismissed. Indonesian workers had an additional problem: they were not eligible for unemployment benefits, as they had been employed unofficially, nor were they eligible for local welfare, which required that one be registered in a municipality for more than a year. These unemployed workers faced the additional misfortune of being too poverty-stricken to afford return tickets to Indonesia. Perkoempoelan Islam stepped into this void of socio-economic despair, both in terms of direct aid and by protecting their interests at the official level. ${ }^{27}$

In Joan Schutzman Wider's interviews with domestic workers in The Hague, she describes how Mohammed Ali van Beetem took direct relief seriously: "When I was sick, he took me to the hospital"; "If a family was not good, he spoke to them or found us another family"; "Once he brought me some coal, when I was not well enough to work." ${ }^{28}$ Van Beetem was also instrumental in

25 John Ingleson, "Fear of the Kampung, Fear of Unrest: Urban Unemployment and Colonial Policy in 1930s Java," Modern Asian Studies 46 (2012), 1639-1643.

26 "Werklooze Suikergeëmployeerden in Nederland; twee duizend Indische werkloozen?" De Indische courant (4 December 1934).

27 Poeze, Politiek-Politioneele Overzichten, Deel III, 423; Ibid., Deel IV, lxxviii.

28 Schutzman Wider, "Indonesian Women in The Hague," 71. 
working for the Indonesian workers at the official level. In June 1933 the association, according to its loyalist views, sent a letter to the Dutch Queen to inform her of the dire situation of Indonesian domestic workers. In this letter, Van Beetem argued that Indies families should be obligated to maintain their servants, and that with a subsidy, Perkoempoelan could ease the most urgent problems. Furthermore, Van Beetem started negotiations with the municipal social service of The Hague, the 'Dienst Maatschappelijk Hulpbetoon' which provided unemployment benefits; he urged them to make an exception to the one-year residency rule for unemployed Indonesians. ${ }^{29}$ Finally, when the langgar opened its doors, a job mediation office for Indonesian servants was established as well. ${ }^{30}$

\section{Loyal but Vulnerable}

Compared to the other Indonesian organizations, the Muslim association had to maintain a balance between loyalty to the state and criticism of its policies. For the nationalists in Perhimpoenan Indonesia it was clear that there was no space for negotiation with the Dutch authorities. And even if there was, they adhered to the position of non-cooperation. At the other end, the moderate 'ethici' were deeply involved in the upper strata of academic life and society, and their journals and associations generally adopted an apolitical stance. The authorities initially approached Perkoempoelan Islam sympathetically, especially with regard to the cemetery and the one-year residency rule. ${ }^{31}$ After all, Perkoempoelan was not a political organization and was outspoken in expressing its loyalty to the queen. The Dutch central intelligence agency even praised the work of Van Beetem because he kept his followers from taking "revolutionary paths." ${ }^{32}$

Nonetheless, despite the loyalist views of Van Beetem, the local and national authorities ultimately adopted an uncooperative attitude towards Perkoempoelan Islam once it started to pursue social aims. For reasons that are

29 "De behandeling van Nederlandsch-Indiers," Algemeen Handelsblad (22 June 1933); "Perkoempoelan Islam," Het Vaderland (29 October 1933); “De Islam, lezing R.A.A. Wiranatakoesoema," De Indische courant (14 November 1933).

$30 \quad$ "Perkoempoelan Islam," Het Vaderland (4 March 1935).

31 "Perkoempoelan Islam, afscheid Van Beetem," Het Vaderland (28 December 1933).

32 "Brieven uit het Moederland," Het Nieuws van den Dag voor Nederlandsch-Indië (28 October 1932); "Deelneming der Perkoempoelan Islam," Het Vaderland (29 March 1934); De Nederlandse Bank archive. 
unclear, the social service suspended payments to Indonesian workers in 1935, and other requests of Perkoempoelan fell on deaf ears. The authorities seemed to be more interested in solving the problem by repatriating the 'foreign' workers, than in mitigating their needs. ${ }^{33}$

In this respect, there are clear similarities with the governmental approach towards other migrant communities in the 1930s, such as the Chinese workers communities of Rotterdam and Amsterdam. The local and national Dutch authorities tried to bring an end to the problem of "the Chinese and other Asian vermin" - as an official at the Ministry of Justice addressed the severely hit community - with a combination of administrative restrictions on immigration, and aid deprivation for the destitute Chinese sailors. ${ }^{34}$ Over ten years' time, the once bustling Chinatowns in Rotterdam and Amsterdam, once home to around three thousand souls, were reduced to around two hundred persons (in 1939). ${ }^{35}$ Although the Netherlands never knew fascist or national-socialist movements of the size of those in Germany and other European countries, authoritarian nationalist governance, xenophobic ideas, and thinking in terms of final solutions were certainly on the rise. Officially, the Indonesians were subjects of the Crown, but that fact did not protect the workers' communities of The Hague; indeed they were still faced with these sentiments and policies. In April 1935, Mohammed Ali van Beetem resigned from his post as secretary of Perkoempoelan Islam as he felt that his many attempts to address the various authorities met no results. ${ }^{36}$

\section{Indonesian, Dutch or European Muslims?}

As indicated above, Perkoempoelan Islam was the only official Muslim association in the Netherlands; its objective was to facilitate the observance of the commandments of Islam. Nonetheless, more significant than its religious character were its social functions as a communal self-help organization for its

33 "De Islam, lezing R.A.A. Wiranatakoesoema," De Indische courant (14 November 1933); "Stopzetting van steun aan Inlanders," Algemeen Handelsblad (10 March 1935); "Indische en Inheemsche werkloozen," De Indische courant (22 June 1935).

Henk J.J. Wubben, Chineezen en Ander Aziatisch Ongedierte: Lotgevallen van Chinese Immigranten in Nederland 1911-1941 (Zutphen:Walburg Pers, 1986); Lucassen and Lucassen, Winnaars en Verliezers, 179-180.

36 "Perkoempoelan Islam," Het Vaderland (15 April 1935); "Indiërs in Nederland: De invloed van extreme elementen, Perkoempoelan Islam," De Indische Courant (1o May 1935). 
members, and as a body for official representation vis-à-vis authorities and employers. In essence Perkoempoelan Islam - of which no non-Muslim Dutchman was member-was a "Dutch" organization in that it was firmly rooted in Dutch society. The Dutch environment, rather than the Islamic world, determined to a large extent its shape and functions. Not surprisingly, Mohammed Ali Van Beetem, who stood with one foot in the Muslim community and with the other in Dutch society, played an important role in representing the Indonesian workers in The Hague, despite being very different from the rank and file of the community.

The "Dutch" and communal character of Perkoempoelan Islam raises the question: to what extent was the organization was connected to the larger Muslim world at all? Were there any attempts to reach out to other Muslim communities, for example, in other countries of western Europe? In France more than 300,000 Muslim workers from the colonized world supplemented the crippled French workforce after World War I. In Britain there were several hundred British converts, and between 10,000 and 20,000 Muslims from British India, Malaysia, and the Arab Peninsula. In Germany, Italy, and Spain thousands of Muslims filled the ranks of the armies, the universities, and the factories. ${ }^{37}$

In the case of Perkoempoelan Islam there is scant archival information on its connections with other groups in Europe. There appear to be two reasons for this lack of information. First and significantly, Perkoempoelan Islam was absent on the radar of Dutch authorities, and hence it remained largely undocumented. Anticolonial Islamist, nationalist or communist organizations were much more distressing to the authorities than the loyalist Perkoempoelan Islam. Neither the documents filed in the archives of the Dutch Ministry of Colonies, nor the monthly reports on political and social action in the Netherlands and the colonies issued by the Dutch East Indies ProcuratorGeneral mention Perkoempoelan Islam. The association is mentioned only twice, and these are references to its loyal and strictly legal approach. ${ }^{38}$ The most informative sources about religious activities are contemporary newspaper articles that do not give information on the organization's involvements with Dutch Indonesian Muslims abroad.

Second, the scarcity of information on international Muslim networks in the Netherlands may also be due to the fact that the domestic workers, cooks, and shopkeepers of Perkoempoelan Islam lacked the international outlook of

37 Clayer and Germain, Islam in Inter-War Europe, 11-15.

38 Poeze, Politiek-Politioneele Overzichten, Deel III, 423; Ibid., Deel IV, 392. 
the Senegalese dockers of Marseille, the Yemeni sailors of Cardiff, or for that matter the Indonesian students of Perhimpoenan Indonesia. The nature of their professions did not stimulate international contacts. Moreover, the raison d'être of their organization was less dependent on propaganda abroad or solidarity from foreign organizations. In contrast to the nationalist Indonesian students in Perhimpoenan Indonesia who, after 1923, consciously established contacts with other anticolonial nationalists in Europe, Perkoempoelan Islam was more concerned with the needs and challenges of its own community in The Hague, than with networking abroad. ${ }^{39}$

\section{Muslim Networks Abroad}

Nonetheless, despite the fragmented source materials, we can distinguish an international side of Islam in the Netherlands. When we examine the transnational networks of Indonesian Muslims beyond the Dutch borders we must discriminate between three types of engagements. First, there were a few occasions in which Indonesian Muslims were in contact with organizations abroad for religious purposes. Second, and more importantly, throughout the 1920 s and 1930s there were political events in which prominent Muslims-Indonesians and non-Indonesians - were involved, though not primarily in the capacity of their religious identity. Finally, the Dutch Indonesian Muslims, workers and students, were in frequent contact with the Indonesian community in Cairo that was deeply embedded in religious institutions.

In the period from 1910 to 1939 I have listed forty-two occasions in which Indonesians in the Netherlands were active abroad, or in which foreigners approached the Dutch Indonesian community for political, organizational or religious purposes. With regard to the first type of engagement, I would label only three of the forty-two events as primarily religious. The most important of these was undoubtedly the presence of Mohammed Ali van Beetem at the European Muslim Congress in Geneva in 1935, which Umar Ryad describes in his article on Van Beetem. ${ }^{40}$ The congress was initiated by the well-known Lebanese pan-Islamic organizer Shakīb Arslān, who fostered an influential network of Muslims in Europe from his residence in Geneva, and who in turn was part of the circles around Muḥammad Rashīd Riḍā and Amīn al-Ḥusaynī.

39 Klaas Stutje, "Indonesian Identities Abroad: International Engagement of Colonial Students in the Netherlands, 1908-1931," BMGN—Low Countries Historical Review 128 (2013), 159 . 
The congress was attended by sixty participants, among them European converts, European Muslims from the Balkans, and immigrants such as Messali Hadj from Algeria. For a number of personal and political reasons the European Muslim Congress turned out to be a disappointment: political issues, internal quarrels, and colliding personalities frustrated the establishment of a permanent European Muslim umbrella organization in the home city of the League of Nations. ${ }^{41}$ For Mohammed Ali van Beetem, however, it provided the opportunity to request-half a year after the inauguration of the langgar-community building in The Hague-moral support for the construction of a proper mosque like the mosques in London, Berlin, and Paris. ${ }^{42}$

A second remarkable religious event was the arrival in the Netherlands of an Ahmadiyya-Lahore missionary, Mirza Ali Ahmad Baig, in $1939 .^{43}$ This Indian propagandist founded an Ahmadiyya center on Java and worked at least twelve years in the Dutch East Indies before he was transferred to the Netherlands. There, he aimed to promote the study of Islam among Indonesian students and establish a mosque. ${ }^{44} \mathrm{He}$ also sought contact with Perkoempoelan Islam, where he soon became a respected member. ${ }^{45}$ It seems that World War II put an early end to Ahmad Baig's activities, as the German authorities imprisoned him. ${ }^{46}$ Nonetheless, the presence of one of the two Ahmadiyya branches in the Netherlands is important: it was this outcast reformist movement of Islam that was at the forefront of institutionalizing Islam in other countries in Europe as well. Its activists devoted much effort and missionary resources to establishing a basic Islamic infrastructure, introducing Islam to non-Muslims, and translating the Qur'ān and other important texts into European languages. They took control of the Woking Mosque in London, and initiated the establishment of mosques in Berlin, Vienna, Madrid, and other European cities. ${ }^{47}$

Although the arrival of Ahmad Baig was most likely the first outward attempt to extend the Ahmadiyya network to the Netherlands, there are

41 Martin Kramer, Islam Assembled: The Advent of the Muslim Congresses (New York: Columbia University Press, 1986), 142-153, there 152.

42 Ryad, "Among the Believers," 301.

43 On the Ahmadiyya and its Lahore and Qadiyani branch, named after the headquarters of both branches, see Clayer and Germain, Islam in Inter-War Europe, 89-118.

44 Poeze, Politiek-Politioneele Overzichten, Deel I, lxxx, 200; Idem, In het Land van de Overheerser, 289; Landman, Van Mat tot Minaret, 23-32; Ryad, "Among the Believers," 304; IISH, Stokvis: inv. nr. 228.

45 "De moskee in Nederland," De Indisch Courant (13 December 1939).

46 This information is derived from an interview with the former chair of the Lahore branch in the Netherlands, Mr. Keeskamp: Landman, Van Mat tot Minaret, 29.

Clayer and Germain, Islam in Inter-War Europe, 28-29, 51, 97-100. 
indications that Indonesian students in the Netherlands were in contact with Indonesian Ahmadis abroad before 1939. In 1927, the Dutch police in Leiden raided the secretariat of the nationalist association Perhimpoenan Indonesia under the pretext of the latter's anticolonial sedition. Among other documents, the police confiscated a list of subscriptions of its journal Indonesia Merdeka. Judging from this list, it would seem that the journal was sent to two addresses in Lahore: the first was a certain Ahmad Sarida, a student of the Ahmadiyya Isha'at Islam college, and the second address was that of the Ahmadiyya Anjuman-i Isha'at-i Islam headquarters itself. ${ }^{48}$ From a couple of years earlier, but confiscated during the same police raid, a small postcard to the Indonesia Merdeka secretariat survived, indicating that the same Ahmad Sarida wanted his address changed from the "Ahmadia Buildings Lahore" to the "Ahmadia School Qadian Gurdaspur Punjab." Sarida also thanked Perhimpoenan Indonesia for sending its journal free of charge. "Your journal is instructive for the Indonesian community here in Lahore and Qadian, which comprises 22 souls. May God help us, Indonesians, in our work: to destroy what is evil."49

Although the relations between the Ahmadiyya branches and the mainstream Muslim world have always been problematic, and the Ahmadiyya movement itself was also split into Qadiyani and Lahori branches, the Dutch historian Harry Poeze concludes from an interview with an Indonesian in The Hague that religious disputes did not affect the Indonesian Muslim community in the Netherlands. ${ }^{50}$ While in Cairo an anti-Ahmadiyya association was established by Jawi students from Padang, in the Netherlands the authority of Ahmad Baig seems to have been widely recognized by the Indonesians. ${ }^{51}$

\section{Student Politics Abroad, Merging Networks}

Connections with other Muslim communities in Europe through political networks occurred much more frequently than through religious networks. This implies, however, that the students in Perhimpoenan Indonesia, by virtue of their attempts to establish political contacts abroad, were much more successful than the workers in Perkoempoelan Islam, who did not focus on foreign representation. While only three primarily religious transnational connections

\footnotetext{
48 NA, Koloniën: inv.nr. 300.

49 NA, Koloniën: inv.nr. 301.

$5^{\circ} \quad$ Poeze, In het Land van de Overheerser, 289.

51 On the anti-Ahmadiyya Majlis Asjaura al Indonesia, see NA, Koloniën: inv.nr. 312 and 314.
} 
were established, no fewer than thirty-five events bore a political or semipolitical character, be they loyalist, nationalist, communist, anticolonial, antifascist or pacifist events. ${ }^{2}$ These non-religious events in Europe served as locations for encounters between prominent Muslims in Europe as well. Political, anticolonial, and religious solidarity were often inter-related.

For example, the Kongress gegen Koloniale Unterdrückung und Imperialismus in Brussels in 1927 was organized at the instigation of the Communist International Red Aid and the Comintern, and bore a strong Communist imprint. ${ }^{53}$ Among historians, this congress is usually studied because of its significance to the anticolonial movement. ${ }^{54}$ Several prominent anticolonial organizers and political leaders from all around the world were present, such as Jawaharlal Nehru of the Indian National Congress and the SenegaleseFrench Communist Lamine Senghor of the Comité de Defense de la Race Nègre. However, among its participants we also find the Indian Mawlana Barkatullah Bhopali, who pursued pan-Islamic and nationalist goals through revolutionary action and who spoke on behalf of the Indian revolutionary Ghadar Party. The prominent Muslim Algerian nationalist Messali Hadj, who lived in France and was involved in the network around the aforementioned Shakīb Arslān was also in attendance. ${ }^{55}$ Mohammed Hatta, the Indonesian student who represented Perhimpoenan Indonesia at the Kongress with a mandate of a number of Indonesian organizations and who later became the first vice president of the independent Indonesian Republic, spoke with various groups, among them Messali Hadj and his Étoile Nord-Africaine. ${ }^{56}$ Although the precise content of the discussions is unknown, in his memoirs

52 These activities do not include the many artistic tours of Noto Soeroto and Jodjana, or holiday trips; see Karels, Mijn Aardse Leven Vol Moeite en Strijd, 91-106.

53 L. Gibarti, Edo Fimmen and Moh. Hatta, Das Flammenzeichen vom Palais Egmont: offzielles Protokoll des Kongresses gegen Koloniale Unterdrückung und Imperialismus, Brüssel, 10-15 Februar 1927 (Berlin: Neuer Deutscher Verlag, 1927); NA, Justitie: inv.nr. 166og; IISH, Henriette Roland Holst: inv. nr. 39; Fredrik Petersson, "We are Neither Visionaries, nor Utopian Dreamers, Willi Münzenberg, the League against Imperialism and the Comintern, 1925-1933" (PhD diss., Åbo Akademi University, 2007), 49, 109.

54 Petersson, "We are Neither Visionaries, nor Utopian Dreamers"; Poeze, Politiek-Politioneele Overzichten, Deel I, xcix-ci.

55 Messali Hadj, Les Mémoires de Messali Hadj 1898-1938 (Paris: J.C. Lattès, 1982), 156-157.

56 The other Dutch Indonesian delegates were Nazir Pamoentjak, Gatot, and Soerbardjo (Manaf). The mandate was given by the parties Partai Nasional Indonesia, Partai Sarekat Islam, Boedi Oetomo, and several student societies, united under the banner of Nationale Concentratie. A fifth Indonesian representative was the Communist Semaoen, representing the Sarekat Rakyat. 
Messali Hadj frequently referred to other participants from Indonesia, Syria, British India, Egypt, Senegal, and Tunisia as his "coréligionnaires." ${ }^{57}$

The Lebanese organizer Shakīb Arslān himself was not present at this event in Brussels, because the French and Belgian authorities did not grant him a visa. ${ }^{58}$ However, ten months later, in November 1927 , the Indonesian students and Perhimpoenan Indonesia members Achmad Subardjo and Sulaiman, had the chance to meet Arslān in Moscow, Messali Hadj from Algeria, and Ahmed Essafi from Tunisia. They met on the occasion of the festivities for the tenth anniversary of the Soviet Union. Apart from communist delegations from all around the world, anticolonial nationalists were invited as part of the Comintern's attempt to gain influence in the colonial world. In his autobiography, Achmad Subardjo describes that his friend Sulaiman - 'a pious Muslim'initially hesitated to accept the invitation because he had heard many negative stories about the treatment of Muslims in the Soviet Union. Nonetheless, they accepted the invitation and during their stay joined the aforementioned Muslim nationalists. When Shakīb Arslān gave a speech in the famous Bolshoi theater in Moscow on the Islamic concept of redistributing wealth among the toiling masses, Subardjo and Sulaiman were greatly inspired. ${ }^{59}$

At first sight, the encounters of Indonesian students with prominent Muslim organizers took place within the context of anticolonialism and the struggle for national liberation. At these moments, they do not seem to have provoked profound theological debates or discussions about the role of Islam in society. ${ }^{60}$ However, because the political events took place on a regular basis, the various Muslim communities became aware of each other's existence. It also may have fueled the idea among some European Muslim organizers to build an international platform on religious grounds as well, of which the aforementioned European Muslim Congress is a telling example.

\section{Cairo and Contacts with the Jawi Community}

Finally, in our attempt to explore the connections between Indonesian Muslims in the Netherlands and Muslims beyond the confines of the Dutch

57 Hadj, Les Mémoires de Messali Hadj, 157.

$5^{8}$ NA, Koloniën: inv.nr. 309; "De Liga; het congres te Brussel," De Indische Courant (10 December 1927).

59 Ahmad Subardjo Djoyoadisuryo, Kesadaran Nasional: Sebuan Otobiografi (Jakarta: Gunung Agung, 1978): 140-144; CARAN 13170.

6o See, for example, the conference proceedings: Gibarti, Fimmen, and Hatta, Das Flammenzeichen vom Palais Egmont. 
Empire we must consider the large Jawi community in Cairo. In the same period that Indonesian students started to arrive in the Netherlands, the first cohorts of Indonesians enrolled in al-Azhar university in Cairo. Contemporary Arabs usually referred to this group as the Jawi; in fact this category comprised people from more cultural backgrounds than the Javanese alone. In fact, all Muslim students in Cairo coming from Muslim lands east of present-day Thailand-including a considerable number of Arabs living in Southeast Asia (the Hadhramis) - came under the rule of the Shaykh alJawi. ${ }^{61}$ Nonetheless, the main group within this Jawi community came from the Dutch East Indies, and considered themselves related to the Indonesians in the Netherlands.

These Jawi students, numbering fourteen in 1904, twenty-two in 1912, 150 in 1925 , and around 100 in the 1930s, established organizations and journals just as the Indonesians in the Netherlands had, though usually on the basis of regional background rather than social class or political affiliation, and they were inspired by Egyptian nationalism and pan-Islamism, rather than by anticolonial nationalism and international communism. ${ }^{62}$ The social background of the average Cairene student differed from that of the Dutch students as well. As mentioned earlier, the Dutch students were typically of aristocratic or merchant descent and from the urban centers on Java, whereas the students in Cairo more often came from religious families and were, in half of the cases, from the west coast of Sumatra.

However, despite these differences, the two communities remained in close contact. The main association of Jawi in Cairo, the Djam'iat al Chairijah, sent its journal Seruan Azhar to Perhimpoenan Indonesia, while the latter organization sent its Indonesia Merdeka in return. ${ }^{63}$ When there were internal quarrels and disagreements in Cairo-and these occurred more often in Cairo than in the Netherlands-Perhimpoenan Indonesia tried to mediate. ${ }^{64}$ On international conferences Perhimpoenan Indonesia, through Achmad Subardjo, was authorized to represent the Djam'iat al Chairijah. ${ }^{65}$ And finally, when prominent Indonesians traveled from Indonesia to Europe, or vice-versa,

61 Michael Laffan, Islamic Nationhood and Colonial Indonesia: The Umma Below the Winds (London: Routledge, 2003), 13, 233; Idem, "An Indonesian Community in Cairo: Continuity and Change in a Cosmopolitan Islamic Milieu," Indonesia 77 (2004): 1-26.

62 Laffan, Islamic Nationhood and Colonial Indonesia, 129, 137-138, 219, 229.

63 NA, Koloniën: inv.nr. 30o; William Roff, "Indonesian and Malay Students in Cairo in the 1920s," Indonesia 9 (1970), 79.

64 NA, Koloniën: inv.nr. 362.

65 Mohammad Hatta, "Het Brusselsche Congres tegen Imperialisme en koloniale onderdrukking en onze buitenlandse propaganda," Indonesia Merdeka 5 (1927), 16. 
they often made a brief stopover in Cairo. There they visited the Jawi community, as did the Muslim cleric Haji Agus Salim on his way to an international labor conference in Geneva in 1930, and Mohammed Hatta on his way back in 1932. ${ }^{66}$ On at least one occasion, an Indonesian Cairo resident paid a visit to the Indonesian community in the Netherlands. The Minangkabau scholar Djanan Tajib was the first Indonesian to have obtained the degree of 'Ālim from al-Azhar and was the chief editor of the Seruan Azhar. When he studied in Paris for six months in 1926 he took the opportunity to meet Hatta and other Indonesian students in Rotterdam. ${ }^{67}$ In Paris, it seems likely that he was in touch with Indonesian activists such as Mononutu and Subardjo.

Of course, the various contacts between Perhimpoenan Indonesia and Djam'iat al Chairijah were not strictly religious. They probably illustrate the evolution of an idea of (proto-)Indonesian communality more than unity on the basis of Islam. However, as the last organization was well embedded in the religious circles in, and Islamic networks radiating from Cairo, it suggests that the militants within Perhimpoenan Indonesia through their contacts with the Djam'iat al Chairijah were at least aware of the religious, semi-religious or political forces in the Islamic world at the time. ${ }^{68}$

Moreover, on at least at one occasion, the pan-Indonesian relations bore an explicitly religious character. As Ryad describes as well, Mohammed Ali van Beetem and Mohammed Rasjid of Perkoempoelan Islam traveled to Egypt in January 1934 to visit Islamic institutions there. ${ }^{69}$ Van Beetem wanted his conversion to Islam recognized by the highly esteemed rector of al-Azhar University, Muhammad al-Aḥmadī l-Ẓawahīī. With the support of Shaykhal-Jawi Burhan el Din (the official representative of the Indonesian students at al-Azhar's board), a special meeting was summoned with religious dignitaries, Egyptian members of parliament, student representatives, and many individual Muslim students from Europe, Asia, America, and Africa. ${ }^{70}$ The trip was a memorable success and granted Van Beetem the prestige and recognition that he had pursued for years.

\footnotetext{
66 NA, Koloniën: inv.nr. 345 and 381; Poeze, In het Land van de Overheerser, 225.

67 Mona Abaza, Changing Images of Three Generations of Azharites in Indonesia (Singapore: Institute of Southeast Asian Studies, 1993), 5 .

68 On the religious environment of the Djam'iat, and the presence of the Jawi Dalhar at the pan-Islamic conference of 1932 in Jerusalem, see NA, Koloniën: inv.nr. 381.

69 Ryad, "Among the Believers," 298-300; "Perkoempoelan Islam, afscheid Van Beetem," Het Vaderland (28 December 1933). Ryad, "Among the Believers," 298-300.
} 


\section{Concluding Remarks}

The journey of Mohammed Ali van Beetem and Mohammed Rasjid to Egypt in 1934 is a striking example of the organized activity of Muslims in the Netherlands in the prewar period, and an example of "Dutch" Muslim involvement with Islamic networks abroad. It can even be argued that Van Beetem and his fellows in Perkoempoelan Islam were consciously part of a 'European Islam,' as they were in contact with Muslim networks around Shakīb Arslān and with Ahmadiyya missionaries such as Mirza Ali Ahmad Baig. ${ }^{11}$

However, this chapter also demonstrates that we need to take into account the other Indonesian organizations in the Netherlands as well, to get a more nuanced impression of the functions and activities of Perkoempoelan Islam. Rather than being a pan-Islamic organization with transnational connections, Perkoempoelan Islam was, first and foremost, a communal organization with strong roots in the Dutch environment. It was more concerned with the accommodation and representation of Indonesian workers vis-à-vis the Dutch authorities than with networking abroad.

Despite Van Beetem's trips to Geneva and Cairo, other Indonesian groups, such as the students in Perhimpoenan Indonesia, were much more active in exercising 'big-politics' in the Dutch Empire and beyond than the Muslim workers in Perkoempoelan Islam were. If we focus on the only group that manifested itself as Islamic, we risk overemphasizing the significance of a few primarily religious activities of Van Beetem, while missing other, although less 'religious' events and encounters, that were important for the Indonesian community in the Netherlands at large.

Notwithstanding these remarks, the interwar presence of Indonesian Muslims and their various organizations in the Netherlands is significant in the context of several research areas: the history of Islam in the Netherlands, the history Islam in interwar Europe, and Indonesian migration to the Netherlands. Moreover, the story of the relatively small Muslim community in Perkoempoelan Islam is illustrative of the attitude the Dutch authorities and the society at large adopted towards migrant communities in general, and of the strategies these communities adopted to cope with their inherently vulnerable position. As such, this aspect of the colonial past is also a key part of Dutch history. 


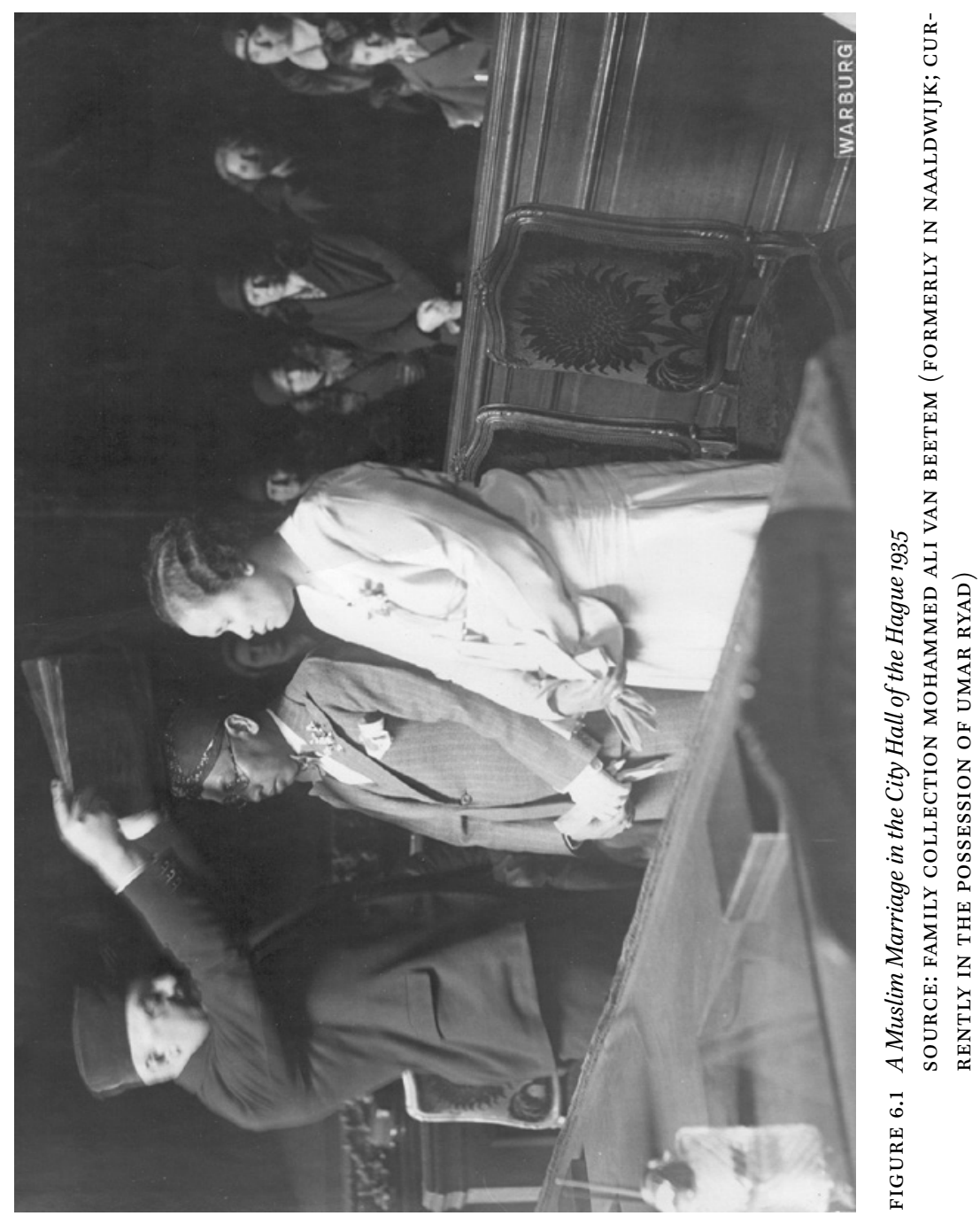




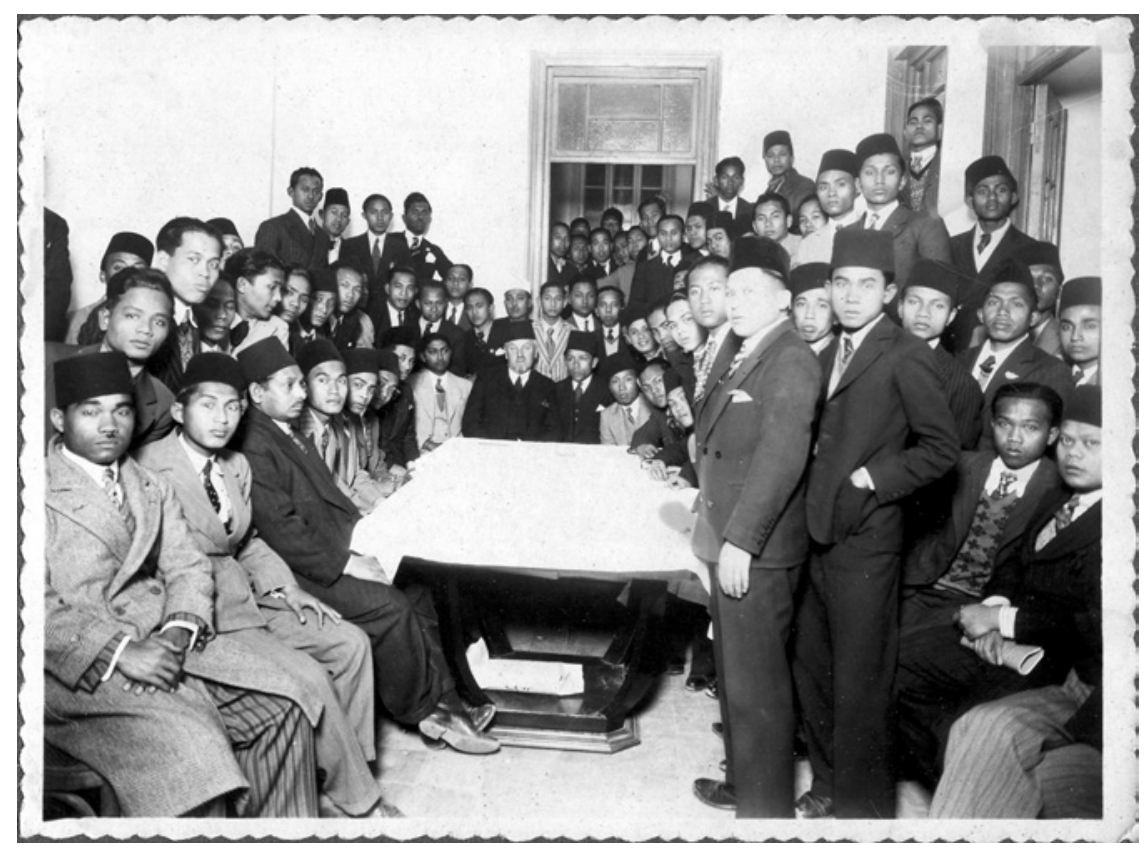

FIGURE 6.2 Van Beetem and Indonesian Students in Cairo 1935

SOURCE: FAMILY COLLECTION MOHAMMED ALI VAN BEETEM (FORMERLY IN NAALDWIJK; CURRENTLY IN THE POSSESSION OF UMAR RYAD)

\section{Bibliography}

\section{Archives}

CARAN $=$ Centre d'Accueil et de Recherche des Archives Nationales Paris. F/7 Police Générale, inventory number 13170, Propagande PCF parmi les indigènes coloniaux. IISH, Henriette Roland Holst = International Institute for Social History Amsterdam (IISH), personal archive Henriette Roland Holst, inventory number 39, collections of articles on the League against Imperialism.

IISH, Stokvis = International Institute for Social History Amsterdam (IISH), personal archive J.E. Stokvis, inventory number 228, Newspaper clippings Achmadyah, Oemmat Islam, studieclubs (etc.).

NA, Justitie = Nationaal Archief Den Haag (NA), Ministerie van Justitie, Verbaalarchief, 1915-1955; Kabinetsarchief, 1915-1940, entry number 2.09.22, inventory number 166o9. NA, Koloniën = Nationaal Archief Den Haag (NA), Ministerie van Koloniën, Geheim Archief, 1901-1940, entry number 2.10.36.51, inventory numbers 236; 300; 301; 309; 310; 312; 314; 345; 362; 381 .

De Nederlandse Bank, inventory number 1.752.000.00o 0120 ha 1.7/38, Centrale Inlichtingen Dienst, Jaargang 1934 Overzicht no. 6. Geheim. Consulted via 
online databank, accessed 14 October 2014: http://resources.huygens.knaw.nl/ rapportencentraleinlichtingendienst.

\section{Literature}

Abaza, Mona. Changing Images of Three Generations of Azharites in Indonesia.

Singapore: Institute of Southeast Asian Studies, 1993.

Algemeen Handelsblad. "De behandeling van Nederlandsch-Indiers." 22 June 1933.

. "Islamieten Vereeniging." 9 October 1932.

. "Stopzetting van steun aan Inlanders." 10 March 1935.

Bachtiar, Harsja W. "The Development of a Common National Consciousness among Students from the Indonesian Archipelago in the Netherlands." Majalah Ilmu-Ilmu Sastra Indonesia 6 (1976): 31-44.

Beetem, J.L.Ch. van. “Een Moskee in Den Haag." Het Vaderland. 15 June 1929.

Clayer, Nathalie and Eric Germain, eds. Islam in Inter-War Europe. London: Hurst \& Company, 2008.

Cottaar, Annemarie. Ik had een Neef in Den Haag: Nieuwkomers in de Twintigste Eeuw. Zwolle: Waanders, 1998.

Djoyoadisuryo, Ahmad Subardjo. Kesadaran Nasional: Sebuan Otobiografi. Jakarta: Gunung Agung, 1978.

Elson, R.E. The Idea of Indonesia: A History. Cambridge: Cambridge University Press, 2009.

Geertz, Clifford. The Religion of Java. Chicago: University of Chicago Press, 1976.

Gibarti, L, Edo Fimmen, and Moh Hatta. Das Flammenzeichen vom Palais Egmont: offzielles Protokoll des Kongresses gegen Koloniale Unterdrückung und Imperialismus, Brüssel, 10-15 Februar 1927. Berlin: Neuer Deutscher Verlag, 1927.

Hadj, Messali. Les Mémoires de Messali Hadj 1898-1938. Paris: J.C. Lattès, 1982.

Hatta, Mohammad. "Het Brusselsche Congres tegen Imperialisme en koloniale onderdrukking en onze buitenlandse propaganda." Indonesia Merdeka 5 (1927): 14-20.

_. "De lezing van Stokvis voor de 'Perhimpoenan Indonesia." De Socialist. 8 June 1929.

De Indische Courant. "Indië in Nederland." 29 February 1932.

—. "Indische en Inheemsche werkloozen." 22 June 1935.

. "Indiërs in Nederland: De invloed van extreme elementen, Perkoempoelan Islam." 10 May 1935.

. "De Islam, lezing R.A.A. Wiranatakoesoema." 14 November 1933.

_. "De Liga; het congres te Brussel." 10 December 1927.

.De moskee in Nederland." 13 December 1939.

- "Werklooze Suikergeëmployeerden in Nederland; twee duizend Indische werkloozen?"4 December 1934.

Ingleson, John. "Fear of the Kampung, Fear of Unrest: Urban Unemployment and Colonial Policy in 1930s Java." Modern Asian Studies 46 (2012): 1633-1671. 
_. Perhimpunan Indonesia and the Indonesian Nationalist Movement, 1923-1928. Melbourne: Monash University, 1975.

Karels, René. Mijn Aardse Leven Vol Moeite en Strijd: Raden Mas Noto Soeroto, Javaan, Dichter, Politicus 1888-1951. Leiden: KITLV Uitgeverij, 2010.

Kramer, Martin. Islam Assembled: The Advent of the Muslim Congresses. New York: Columbia University Press, 1986.

Laffan, Michael. "An Indonesian Community in Cairo: Continuity and Change in a Cosmopolitan Islamic Milieu." Indonesia 77 (2004): 1-26.

_. Islamic Nationhood and Colonial Indonesia: The Umma Below the Winds. London: Routledge, 2003.

Landman, Nico. Van Mat tot Minaret: de Institutionalisering van de Islam in Nederland. Amsterdam: vu Uitgeverij, 1992.

Locher-Scholten, Elsbeth. Ethiek in fragmenten. Vijf studies over koloniaal denken en doen van Nederlanders in de Indonesische Archipel 1877-1942. Utrecht: Hes Publishers, 1981.

Lucassen, Jan and Leo Lucassen. Winnaars en Verliezers: Een Nuchtere Balans van Vijfhonderd Jaar Immigratie. Amsterdam: Uitgeverij Bert Bakker, 2012.

Het Nieuws van den Dag voor Nederlandsch-Indië. "Brieven uit het Moederland." 28 October 1932.

Het Nieuwsblad van het Noorden. "Verbond van Nationalisten." 10 March 1928.

Petersson, Fredrik. "We are Neither Visionaries, nor Utopian Dreamers, Willi Münzenberg, the League against Imperialism and the Comintern, 1925-1933." $\mathrm{PhD}$ dissertation, Åbo Akademi University, 2007.

Poeze, Harry A. In het Land van de Overheerser, I: Indonesiërs in Nederland 1600-1950. Dordrecht: Foris Publications Holland, 1986.

- Politiek-Politioneele Overzichten van Nederlandsch-Indië: Deel I-IV. Dordrecht: Foris Publications Holland, 1982-1994.

Roff, William. "Indonesian and Malay Students in Cairo in the 1920s." Indonesia 9 (1970): $73-87$.

Ryad, Umar. "Among the Believers in the Land of the Colonizer: Mohammed Ali van Beetem's Role Among the Indonesian Community in the Netherlands in the Interwar Period." Journal of Religion in Europe 5 (2012): 273-310.

_ . "Te Gast in Den Haag: Discussies Moskeebouw in Nederland vóór de Tweede Wereldoorlog." Tijdschrift voor Religie, Recht en Beleid 4 (2013): 59-78.

Schutzman Wider, Joan. "Indonesian Women in The Hague: Colonial Immigrants in the Metropolis." PhD diss., New York University, 1967.

Shadid, W.A.R and P.S. van Koningsveld. Islam in Nederland en België: Religieuze Institutionalisering in Twee Landen met een Gemeenschappelijke Voorgeschiedenis. Leuven/Paris/Dudley, mA: Peeters, 2008.

Stutje, Klaas. "Indonesian Identities Abroad: International Engagement of Colonial Students in the Netherlands, 1908-1931." BMGN_Low Countries Historical Review 128 (2013): 151-172. 
De Sumatra Post. "Perhimpoenan Indonesia; de ervaringen van Stokvis." 8 July 1929.

Sutherland, H.A. The Making of a Bureaucratic Elite: The Colonial Transformation of the Javanese Priyayi. Singapore: Heinemann Educational Books, 1979.

Het Vaderland. "Deelneming der Perkoempoelan Islam.” 29 March 1934. . "Islamietische Begraafplaats." 24 December 1932.

_. "Perkoempoelan Islam." 29 October 1933.

_. "Perkoempoelan Islam." 4 March 1935.

—. "Perkoempoelan Islam." 15 April 1935.

—_. "Perkoempoelan Islam, afscheid Van Beetem." 28 December 1933.

—. "Verbond van Nationalisten." 26 March 1929.

—_. "Verkiezingen Tweede Kamer, de candidaatstelling." 21 May 1929.

—. "Viering van het Indisch Nieuwjaar." 28 January 1933.

Wubben, Henk J.J. Chineezen en Ander Aziatisch Ongedierte: Lotgevallen van Chinese Immigranten in Nederland 1911-1941. Zutphen: Walburg Pers, 1986. 